\title{
Hubungan antara Tingkat Pengetahuan Pasien dan Pengawas Menelan Obat (PMO) dengan Kepatuhan Pasien Tuberkulosis di Puskesmas Kabupaten Jember (Correlation Between Knowledge And Patient Adherence Among Tuberculosis Patients And Their Treatment Observers In J ember Regency, East J ava)
}

\author{
Antonius Nugraha Widhi Pratama, Amelya Prastica Rahayu Aliong, Nili Sufianti, Ema \\ Rachmawati \\ Fakultas Farmasi Universitas Jember \\ JIn. Kalimatan 37, Jember 68121 \\ E-mail korespondensi: anton.farmasi@unej.ac.id
}

\begin{abstract}
Tuberculosis (TB) is an infectious disease that mostly affects developing countries. In Indonesia, TB incidence increases every year due to patient inadherence to the standard DOTS therapy. The TB patients inadherence can be associated with poor knowledge among patients and treatment observers. This cross-sectional research aimed to explore the correlation between knowledge level of TB patients and their treatment observers and patient adherence. Purposive sampling technique was used to collect data from 65 respondents from their primary health centers in Jember Regency, East Java. Knowledge of the respondents was evaluated using a 16 items questionnaire and patient adherence was assesed using the translated version of morisky medication adherence scale-8 (MMAS-8) questionnaire. The Spearman R ho correlation test resulted in $p$ value of 0,043 between patients knowledge and patients adherence. Statistically significant correlation was also found between the knowledge of treatment observers and TB patients adherence $(p=0,015)$. These results suggested the needs to improve knowledge about TB not only for TB patients, but also their treatment observers.
\end{abstract}

Keywords: TB patient, treatment observer, knowledge, compliance

\begin{abstract}
Abstrak
Tuberkulosis (TB) merupakan penyakit infeksi yang terjadi di seluruh dunia. Di Indonesia, kejadian TB meningkat setiap tahunnya karena masalah ketidakpatuhan pasien TB dalam terapi DOTS. Ketidakpatuhan pasien berhubungan dengan pengetahuan pasien. Penelitian cross-sectional ini bertujuan untuk mengetahui korelasi tingkat pengetahuan pasien TB dan PMOnya terhadap kepatuhan pasien TB paru. Teknik purposive sampling digunakan untuk mengumpulkan data dari 65 responden dari Puskesmas tempatnya berobat di Kabupaten Jember, Jawa Timur. Pengetahuan responden dievalusi menggunakan kuesioner yang berisi 16 pernyataan dan kepatuhan pasien dinilai menggunakan kuesioner morisky medication adherence scale-8 (MMAS-8) yang sudah diterjemahkan. Uji korelasi Spearman menghasilkan nilai $p$ sebesar 0,043 antara pengetahuan pasien dan kepatuhan pasien. Secara statistik, hubungan yang signifikan juga ditemukan antara pengetahuan PMO dan kepatuhan pasien $(p=0,015)$. Hasil ini menunjukkan bahwa pengetahuan tentang TB perlu ditingkatkan bukan hanya pada pasien tetapi juga pada PMOnya.
\end{abstract}

Kata kunci: pasien TB, pengawas menelan obat, pengetahuan, kepatuhan 
Pratama, et al., Hubungan Antara Tingkat Pengetahuan Pasien dan Pengawas Menelan Obat (PMO)....

\section{Pendahuluan}

Tuberkulosis (TB) adalah penyakit infeksi menular yang disebabkan oleh Mycobacterium tuberculosis [1]. Saat ini TB menjadi penyebab kematian kedua di dunia, dengan sepertiga dari penduduk dunia telah terinfeksi oleh TB. Indonesia masih masuk dalam kategori high burden countries, dengan insiden dan prevalensi tertinggi rangking 2 setelah India dengan persentase $10 \%$ dan masuk dalam tiga besar prevalensi mortalitas TB tertinggi. Selain itu, Indonesia juga masuk ke dalam kategori negara dengan kasus multi drug resistance tuberculosis (MDR-TB) tertinggi [2]. Berdasarkan data jumlah kasus TB Dinas Kesehatan Jember pada tahun 2012, 2013, dan 2014 angka kasus TB yang terjadi di Kabupaten Jember berturut-turut ialah 2.994, 2.781, dan 3.139 [3].

Sejalan dengan meningkatnya kasus TB, program nasional pengendalian TB mulai menerapkan strategi pengobatan jangka pendek dengan pengawasan langsung yaitu directly observed treatment short-course (DOTS) yang dilaksanakan di puskesmas secara bertahap. Sejak tahun 2000, strategi DOTS dilaksanakan secara nasional di seluruh Fasilitas Pelayanan Kesehatan terutama puskesmas yang diintegrasikan dalam pelayanan kesehatan dasar. Strategi DOTS terdiri dari 5 komponen kunci yaitu komitmen politis, penemuan kasus, pengobatan standar, sistem pengelolaan dan ketersediaan obat anti TB (OAT) serta sistem monitoring [4].

Menurut Laporan Kabid Pemberantasan Penyakit dan Penyehatan Lingkungan (P2PL) Dinas Kesehatan Kabupaten Jember, pada tahun 2014 terdapat 11 pasien yang telah terdiagnosis sebagai pasien MDR-TB dengan 2 diantaranya telah meninggal dunia [5]. MDR-TB dapat terjadi dikarenakan ketidakpatuhan pasien dalam proses pengobatan TB yang dapat mengakibatkan terjadinya resistensi OAT. Hal tersebut dikarenakan proses pengobatan TB membutuhkan waktu yang lama sehingga kebanyakan pasien TB merasa terbebani dengan proses pengobatan. Menurut Ni'mah et al., [6] dalam penelitiannya mengenai riwayat kepatuhan pengobatan TB pasien MDR-TB di Kabupaten Jember, sebagian responden yang merupakan warga Kabupaten Jember memiliki tingkat pengetahuan kurang (66\%) dengan separuh responden memiliki riwayat pengobatan tidak patuh (33\%).

Masalah ketidakpatuhan tersebut dapat diminimalkan dengan adanya pengawas menelan obat (PMO) yang dapat mengingatkan dan mengawasi pasien TB saat melakukan pengobatan. Menurut hasil studi pendahuluan yang dilakukan di Puskesmas Tanggul pada tahun 2013, lima orang pasien TB paru mengatakan bahwa pasien meminum obat sendiri tanpa didampingi PMO. PMO jarang untuk mengingatkan dan mengawasi pasien saat minum obat [7]. Hasil tersebut menunjukkan bahwa PMO masih belum paham mengenai tugasnya untuk selalu mendampingi dan memotivasi pasien saat melakukan pengobatan. Hal ini diduga berkaitan dengan pengetahuan $\mathrm{PMO}$ tentang penyakit TB dan pengobatannya. Mengacu dari beberapa hal diatas maka peneliti tertarik untuk melakukan penelitian tentang pegetahuan pasien TB dan PMO yang selanjutnya akan dilihat hubungan dari kedua varibel tersebut.

\section{Metode Penelitian}

Penelitian ini merupakan penelitian survei analitik dengan jenis penelitian cross sectional. Penelitian ini dilakukan dengan memberikan kuesioner pengetahuan kepada pasien dan PMO serta kuesioner kepatuhan morisky medication adherence scale-8 (MMAS8) kepada pasien. Metode tersebut digunakan untuk mengetahui hubungan antara variabel pengetahuan pasien dan PMO dengan kepatuhan pasien TB.

Pengambilan data dilakukan di 3 tempat yaitu Puskesmas Kaliwates, Patrang, dan Mayang Kabupaten Jember. Pengumpulan data dilakukan dari bulan Oktober - Desember 2016. Populasi dalam penelitian ini adalah pasien TB dan PMOnya yang masuk ke dalam kriteria inklusi. Kriteria inklusi untuk responden pasien yaitu bersedia menjadi responden dengan mengisi lembar informed consent, berusia dewasa 15-60 tahun, penderita yang sudah didiagnosis TB paru baru, sudah menjalani pengobatan minimal selama 2 minggu, mendapatkan obat KDT dan masih dalam pengobatan tahap intensif. Kriteria inklusi untuk responden PMO yaitu berumur 15-60 tahun dan merupakan PMO dari penderita TB yang termasuk dalam kriteria inklusi (pasangan dari penderita yang diberi kuesioner kepatuhan). Kriteria eksklusi penelitian yaitu PMO dan pasien yang tidak bersedia menjadi responden dan tidak mengambil obat di Puskesmas Patrang, Kaliwates, dan Mayang. Pengambilan sampel dilakukan dengan menggunakan teknik purposive sampling. Sampel yang diambil dalam 
Pratama, et al., Hubungan Antara Tingkat Pengetahuan Pasien dan Pengawas Menelan Obat (PMO)....

penelitian ini merupakan semua populasi yang memenuhi kriteria inklusi yang sudah ditentukan.

Tingkat pengetahuan pasien dan PMO dibagi menjadi 3 kategori yaitu tinggi (skor > $80 \%$ ), sedang (skor $60-80 \%$ ), rendah (skor < $60 \%$ ) [8]. Tingkat kepatuhan penderita juga dibagi menjadi 3 kategori yaitu tinggi $($ skor $=8$ ), sedang (skor 6-7), dan rendah (skor < 6) [9]. Analisis data menggunakan uji Spearman. Interpretasi data hasil uji korelasi Spearman adalah dengan melihat level signifikansi (nilai p) sebesar 0,05 . Bila nilai $p$ lebih kecil dari 0,05 maka hipotesis nol (HO) ditolak atau dapat dinyatakan terdapat hubungan yang bermakna antara dua variabel.

\section{Hasil Penelitian}

\section{Faktor demografi}

Hasil penelitian pada Tabel 1 menunjukan responden yang merupakan $\mathrm{PMO}$ mayoritas perempuan $76,7 \%$, berusia 26-35 tahun $(46,7 \%)$, berpendidikan terakhir SMA $36,7 \%$, merupakan Ibu Rumah Tangga (IRT) 43,3\%, dan berstatus sebagai suami/istri dari pasien TB paru.

Pasien TB paru yang menjadi responden berjumlah 35 orang, 5 diantaranya tidak memiliki PMO. Pasien TB paru mayoritas berumur 36-45 tahun (30\%), berpendidikan terakhir SD $(36,7 \%)$, dan merupakan Ibu Rumah Tangga $33,3 \%$.

\section{Hubungan tingkat pengetahuan PMO terhadap tingkat kepatuhan pasien}

Tabel 2 menunjukan bahwa tingkat pengetahuan PMO mengenai TB, gejala, pengobatan, pencegahan, dan sikap yang harus dilakukan ialah sedang (46,7\%). Sedangkan, tingkat kepatuhan pasien TB paru dalam pengobatan ialah tinggi (50\%). Hasil analisis hubunga tingkat pengetahuan terhadap tingkat kepatuhan pasien diperoleh nilai $p$ sebesar 0,015 dengan korelasi hubungan sebesar 0,44.

\section{Hubungan tingkat pengetahuan pasien terhadap tingkat kepatuhan pasien TB paru \\ Tabel 3 menunjukan bahwa mayoritas pasien TB paru di ke tiga puskesmas memiliki tingkat pengetahuan yang sedang $(n=28,80 \%)$ dan tingkat kepatuhan dalam pengobatan yang sedang $(n=16,45,7 \%)$ pula. Hasil analisis hubungan tingkat pengetahuan terhadap tingkat kepatuhan pasien diperoleh nilai $p$ sebesar 0,043 dengan korelasi hubungan sebesar 0,345 .}

Tabel 1. Karakteristik responden penelitian

\begin{tabular}{lrr}
\hline Karakteristik & \multicolumn{1}{c}{ PMO } & \multicolumn{1}{c}{ Pasien } \\
\cline { 2 - 3 } responden & $\mathbf{N}(\%)$ & \multicolumn{1}{c}{$\mathbf{N}(\%)$} \\
\hline J enis kelamin & & \\
Perempuan & $23(76,7)$ & $18(51,5)$ \\
Laki-laki & $7(23,3)$ & $17(48,6)$ \\
Usia (tahun) & & \\
15-25 & $4(13,3)$ & $6(17,1)$ \\
26-35 & $14(46,7)$ & $7(20)$ \\
36-45 & $8(26,7)$ & $10(28,6)$ \\
46-50 & $4(13,3)$ & $4(11,4)$ \\
>50 & $0(0)$ & $8(22,9)$ \\
Pendidikan terakhir & & \\
Tidak Sekolah & $0(0)$ & $4(11,4)$ \\
SD & $8(26,7)$ & $12(34,3)$ \\
SMP & $4(13,3)$ & $6(17,1)$ \\
SMA & $11(36,7)$ & $8(22,9)$ \\
PT & $7(23,3)$ & $5(14,3)$ \\
Pekerjaan & & \\
Tidak bekerja & $0(0)$ & $5(14,3)$ \\
lbu rumah tangga & $13(43,3)$ & $11(31,4)$ \\
Pegawai swasta & $5(16,7)$ & $6(17,1)$ \\
Wiraswasta & $7(23,3)$ & $10(28,6)$ \\
PNS & $2(6,7)$ & $1(2,9)$ \\
Pelajar & $3(10)$ & $2(5,7)$ \\
Status PMo & & \\
Orang tua & $5(16,7)$ & - \\
Suami/istri & $12(40)$ & - \\
Anak & $8(26,7)$ & - \\
Saudara & $3(10)$ & - \\
Tetangga & $1(3,3)$ & - \\
Kader & $1(3,3)$ & - \\
Total & $\mathbf{3 0}(\mathbf{1 0 0})$ & $\mathbf{3 5}(\mathbf{1 0 0})$
\end{tabular}

\section{Pembahasan}

Faktor demografi terhadap prevalensi TB
paru

Berdasarkan faktor demografi responden yang dikaitkan dengan kejadian TB paru yang terjadi terdapat mayoritas pasien TB paru berusia $36-45$ tahun (28,57\%). Berdasarkan Kemenkes [10] TB umumnya terjadi pada usia produktif yakni 15-50 tahun. Hal ini juga sesuai dengan penelitian yang dilakukan oleh Rukmini [11] yang mengatakan bahwa usia produktif memiliki risiko yang lebih tinggi terhadap penyakit TB.

Berdasarkan jenis kelamin, didapatkan bahwa pasien TB paru mayoritas merupakan 
Pratama, et al., Hubungan Antara Tingkat Pengetahuan Pasien dan Pengawas Menelan Obat (PMO)....

Tabel 2. Hubungan tingkat pengetahuan $\mathrm{PMO}$ terhadap tingkat kepatuhan pasien

\begin{tabular}{cccccc}
\hline Skor & Tinggi & Sedang & Rendah & Total & Nilai p \\
\hline Tingkat pengetahuan PMO, $\mathbf{n}(\%)$ & $3(10)$ & $14(46,7)$ & $13(43,3)$ & \multirow{2}{*}{$30(100)$} & \multirow{2}{*}{0,015} \\
\hline Tingkat kepatuhan pasien, $\mathbf{n}(\%)$ & $15(50)$ & $12(40)$ & $3(10)$ & & \\
\hline
\end{tabular}

Tabel 3. Hubungan tingkat pengetahuan terhadap tingkat kepatuhan pasien

\begin{tabular}{lccccc}
\hline & Tinggi & Sedang & Rendah & Total & Nilai $\mathbf{p}$ \\
\hline Tingkat pengetahuan pasien, n (\%) & $5(14,3)$ & $28(80)$ & $2(5,7)$ & \multirow{2}{*}{$35(100)$} & \multirow{2}{*}{0,043} \\
\cline { 1 - 5 } Tingkat kepatuhan pasien, $\mathbf{n}(\%)$ & $15(42,9)$ & $16(45,7)$ & $4(11,4)$ & & \\
\hline
\end{tabular}

perempuan (51,5\%). Perbandingan jumlah responden perempuan dan laki-laki ialah kurang lebih 1:1. Menurut Erwatyningsih [12] TB lebih berisiko terjadi pada laki-laki dikarenakan beban kerja laki-laki lebih berat dan umumnya memiliki gaya hidup yang kurang sehat seperti merokok dan minum alkohol.

Berdasarkan pekerjaan, mayoritas pasien TB paru merupakan lbu Rumah Tangga (IRT) $(31,4 \%)$. Menurut Fatimah [13] terdapat hubungan antara lingkungan rumah terhadap risiko penyebab terjadinya TB di lingkungan rumah. Faktor-faktor tersebut diantaranya pencahayaan, luas ventilasi, kebiasaan membuka jendela, kelembapan, suhu, dan jenis dinding. Berkaca pada penelitian tersebut, kemungkinan risiko terjadinya penyakit TB pada IRT dapat terjadi.

Berdasarkan pendidikan akhir, mayoritas pasien TB paru memiliki pendidikan terakhir Sekolah Dasar (SD) (34,3\%). Sesuai dengan hasil Riskesdas 2007 menemukan bahwa prevalensi TB paru empat kali lebih tinggi pada pendidikan rendah dibandingkan pendidikan tinggi [14].

Sedangkan berdasarkan demografi responden yang merupakan $\mathrm{PMO}$, mayoritas PMO adalah perempuan (76,7\%). Hal ini dapat disebabkan karena PMO dengan jenis kelamin perempuan lebih bersedia untuk menjadi responden dan mengisi kuesioner. Biasanya, PMO dengan jenis kelamin perempuan juga lebih peduli untuk mengawasi dan mengingatkan pasien TB untuk minum obat maupun cek dahak ulang ke Puskesmas. Perempuan memiliki sifat sabar dan telaten sehingga mereka mampu melaksanakan tugas sebagai PMO dengan baik [15].

Dalam penelitian ini, mayoritas PMO dari pasien TB paru berada pada usia 26-35 tahun $(46,7 \%)$. Hasil ini sesuai dengan hasil penelitian Fauzi [16] yang memberikan gambaran bahwa karakteristik PMO berdasarkan usia yang lebih diharapkan oleh pasien TB paru yaitu berusia 20-30 tahun. Seseorang yang berusia 26-35 tahun dapat dikatakan sudah matang secara fisik, psikis dan sosial sehingga lebih baik dalam menerima dan menyampaikan sesuatu.

Pendidikan terakhir yang dimiliki oleh mayoritas PMO adalah SMA (36,7\%). Semakin tinggi tingkat pendidikan seseorang maka akan semakin baik pula orang tersebut menerima dan menyampaikan informasi khususnya terkait penyakit TB dan pengobatannya. Pendidikan PMO dapat mempengaruhi tingkat pengetahuan tentang materi pelayanan pengawasan pasien TB paru. Semakin tinggi pendidikan PMO maka semakin tinggi pula tingkat pengetahuannya, sehingga secara tidak langsung juga akan mempengaruhi terjadinya praktik PMO terhadap pasien TB paru [17].

Pekerjaan yang dimiliki oleh mayoritas PMO adalah ibu rumah tangga (43,3\%). Hal ini dapat disebabkan karena mayoritas PMO adalah perempuan dengan usia 26-35 tahun yang biasanya lebih memiliki banyak waktu luang dibandingkan PMO dengan pekerjaan yang lain. Hal ini sesuai dengan penelitian yang menyebutkan bahwa kebanyakan PMO adalah ibu rumah tangga yang hanya beraktivitas di rumah dan lingkungannya, serta dapat meluangkan waktunya untuk wawancara pada hari-hari dan jam yang digunakan kebanyakan orang untuk bekerja [18].

PMO dari pasien TB lebih banyak berasal dari keluarga inti $(93,3 \%)$ khususnya suami atau istri. Pemilihan PMO biasanya diutamakan dari keluarga pasien karena keluarga adalah orang terdekat yang setiap saat bisa mengawasi pasien pada saat minum obat. Selain itu karena adanya ikatan batin antara penderita dengan PMO yang berasal dari keluarganya sehingga dimungkinkan dapat meningkatkan perilaku PMO tersebut [17]. 


\section{Hubungan tingkat pengetahuan PMO terhadap tingkat kepatuhan pasien}

Berdasarkan hasil penelitian, mayoritas PMO memiliki tingkat pengetahuan yang sedang (70\%). Hal ini disebabkan karena informasi yang sering disampaikan oleh petugas TB hanya terkait penyebab penyakit, lama pengobatan, jumlah obat yang harus diminum setiap harinya, pentingnya pengobatan teratur dan tuntas, serta pencegahan yang bisa dilakukan. Informasi lain tentang tugas dan tindakan yang harus dilakukan saat terjadi efek samping tidak disampaikan oleh petugas poli TB di puskesmas.

Pada penelitian ini, pasien yang memiliki tingkat kepatuhan tinggi berjumlah sebanyak 15 responden (50\%). Kepatuhan pasien TB Paru yang diukur mencakup kepatuhan meminum obat dengan cara yang benar, jumlah obat yang diminum sesuai petunjuk petugas kesehatan, pernah terlambat minum obat, dan pernah lupa minum obat [19].

Hubungan tingkat pengetahuan PMO terhadap tingkat kepatuhan pasien TB paru berdasarkan uji analisis korelasi Spearman, didapatkan nilai koefisien korelasi ( $r$ ) sebesar 0,44 yang menandakan adanya korelasi yang moderat $(0,30-0,49)[20]$.

Nilai level signifikansi $(p)$ yang didapat pada penelitian ini adalah 0,015 yang artinya nilai $p<0,05$ sehingga dapat disimpulkan bahwa terdapat hubungan yang signifikan antara tingkat pengetahuan PMO dengan tingkat kepatuhan pasien TB di Puskesmas Kabupaten Jember. Hal ini sesuai dengan penelitian yang menyatakan bahwa ada hubungan yang signifikan antara tingkat pengetahuan PMO dengan tingkat kepatuhan pasien TB [18]. Pada penelitian ini, mayoritas pasien TB paru patuh karena memiliki kesadaran diri untuk berobat. Perilaku pasien TB paru yang seperti ini merupakan salah satu perilaku yang ditunjukkan oleh pasien karena pasien merasa terbebani dengan penyakitnya sehingga pasien ingin menjalani pengobatan seperti yang disarankan oleh tenaga kesehatan. Pasien TB paru juga menyadari beberapa risiko yang akan dialami jika mereka tidak patuh dalam pengobatan. Selain itu, adanya PMO yang memiliki pengetahuan cukup tinggi tentang penyakit TB dan pengobatannya juga menimbulkan perilaku untuk selalu mengingatkan dan mengawasi pasien TB saat melakukan pengobatan serta memberikan motivasi kepada pasien TB untuk tetap patuh dalam pengobatan.

\section{Hubungan tingkat pengetahuan terhadap tingkat kepatuhan pasien TB paru \\ Pada penelitian ini pasien TB paru} memiliki tingkat pengetahuan yang sedang $(n=$ 28 ; 80\%) mengenai penyakit TB, gejala, pengobatan, pencegahan, efek samping, dan sikap pasien terhadap efek samping yang ditimbulkan. Pengetahuan pasien mengenai TB diperoleh dari petugas TB di Poli TB Puskesmas. Sedangkan tingkat kepatuhan pasien dalam pengobatan juga berada di tingkat sedang $(n=16 ; 45,7 \%)$.

Hubungan tingkat pengetahuan penderita TB dengan tingkat kepatuhannya dalam proses pengobatan telah diuji menggunakan analisis statistik Spearman. Didapatkan nilai $p$ sebesar $0,043<0,05$ sehingga dapat dikatakan bahwa $\mathrm{HO}$ ditolak maka terdapat hubungan yang signifikan antara tingkat pengetahuan penderita dengan tingkat kepatuhannya. Nilai koefisien korelasi sebesar 0,345 berdasarkan tabel makna nilai korelasi rank Spearman maka dapat dikatakan bahwa hubungan yang terdapat antara kedua parameter yakni hubungan yang moderat $(0,30$ 0,49) [20].

Pengetahuan pasien TB paru mengenai penyakit TB, pengobatan yang diperlukan dan lamanya pengobatan yang harus dilakukan mempengaruhi kepatuhan penderita untuk berobat secara tuntas [21]. Hasil penelitian ini sesuai dengan penelitian yang dilakukan oleh Mukhsin [22] bahwa pendidikan, pengetahuan, dan sikap menunjukkan adanya hubungan yang signifikan dengan kepatuhan berobat pada pasien TB paru. Tingkat pengetahuan pasien yang rendah akan berisiko lebih dari dua kali terjadi kegagalan pengobatan dibandingkan dengan penderita yang memiliki pengetahuan tinggi.

\section{Simpulan dan Saran}

Pasien dan PMO di Puskesmas Patrang, Kaliwates, dan Mayang Kabupaten Jember memiliki tingkat pengetahuan yang sedang dan tingkat kepatuhan yang dimiliki oleh pasien TB juga berada pada tingkat sedang. Hasil analisis statistik menunjukkan bahwa terdapat hubungan yang moderat antara tingkat pengetahuan pasien TB paru dan PMO terhadap tingkat kepatuhannya dalam berobat dengan nilai $p$ berturut-turut untuk pasien TB dan PMO yaitu 0,021 dan 0,015 . Peneliti menyarankan perlu dilakukan penelitian lebih lanjut mengenai pemberian edukasi menggunakan metode tertentu untuk meningkatkan pengetahuan 
Pratama, et al., Hubungan Antara Tingkat Pengetahuan Pasien dan Pengawas Menelan Obat (PMO)....

pasien TB dan PMO khususnya di Kabupaten Jember.

\section{Ucapan Terima Kasih}

Peneliti mengucapkan banyak terima kasih kepada keluarga besar peneliti yang telah memberikan bantuan materil dalam pelaksanaan penelitian ini. Selain itu, ucapan terima kasih juga disampaikan kepada Badan Kesatuan Bangsa dan Politik serta Dinas Kesehatan Kabupaten Jember yang telah membantu administrasi penelitian ini. Peneliti juga mengucapkan terima kasih kepada petugas poli TB di Puskesmas Patrang, Kaliwates dan Mayang Kabupaten Jember yang telah membantu pelaksanaan penelitian ini.

\section{Daftar Pustaka}

[1]Price, SA. Patofisologi: konsep klinis prosesproses penyakit. Edisi Keenam Volume 2. Jakarta: EGC; 2006.

[2]World Health Organization. Global tuberculosis report 20th ed. Geneva: World Health Organization; 2015.

[3]Jember. Dinas Kesehatan. Data pencapaian program TB. Jember: Dinas KesehataN Kabupaten Jember; 2014.

[4]Kementrian Kesehatan Republik Indonesia. Tuberkulosis: temukan obati sampai sembuh. Jakarta: Direktorat Jenderal Pengendalian Penyakit dan Penyehatan Lingkungan; 2015.

[5]Jember. Dinas Kesehatan. Laporan pasien tuberkulosis. Jember: Dinas Kesehatan Kabupaten Jember; 2014.

[6]Ni'mah, Al. Riwayat kepatuhan pengobatan TB pasien MDR-TB di Kabupaten Jember tahun 2014. Artikel Ilmiah Hasil Penelitian Mahasiswa. 2014.

[7]Erlinda, R., Wantiyah, dan Dewi, El. Hubungan peran pengawas minum obat (PMO) dalam program directly observed treatment shortcourse (DOTS) dengan hasil apusan BTA pasien tuberkulosis paru di Puskesmas Tanggul Kabupaten Jember. Pustaka Kesehatan [Internet]. 2013 [Diakses pada tanggal 24 Februari 2016]. Tersedia di: http://repository.unej.ac.id/bitstream/handle/1 23456789/60670/Rindy\%20Erlinda.pdf Sequence $=1$

[8]Khomsan, A. Pangan dan gizi untuk kesehatan. Jakarta: Rajagrafino Persada; 2002.

[9]Morisky, DE., Ang, A., Krousel-Wood, M., dan Ward, JH. Predictive validity of a medication adherence measure in an outpatient setting. J Clin Hypertens (Greenwich). 2008: 10(5): 348-354.

[10]Kementrian Kesehatan Republik Indonesia. Pedoman nasional pengendalian tuberkulosis. Jakarta: Kemenkes RI; 2014.

[11]Rukmini dan Chatarina, U. W. Faktor-faktor yang berpengaruh terhadap kejadian TB paru dewasa di Indonesia (analisis data riset kesehatan dasar tahun 2010). Buletin Penelitian Sistem Kesehatan. 2011: 14(4): 329.

[12]Erawatyningsih, E., Purwanta, dan Subekti, $\mathrm{H}$. Faktor-faktor yang mempengaruhi ketidakpatuhan berobat pada penderita tuberkulosis paru. Berita Kedokteran Masyarakat. 2009: 25 (3): 118.

[13]Fatimah, S. Faktor kesehatan lingkungan rumah yang berhubungan dengan kejadian TB paru di Kabupaten Cilacap (Kecamatan: Sidorejo, Cipari, Kedungrejo, Pahmuang, Gandung Mangu, Bantarsari) tahun 2008. Tesis. Semarang: Program Pasca Sarjana UNDIP; 2008.

[14]Badan Litbang Depkes RI. Riset kesehatan dasar 2007. Jakarta: Depkes Rl; 2008.

[15]Hapsari, JR. Hubungan kinerja pengawas minum obat (PMO) dengan keteraturan berobat pasien TB paru strategi DOTS di RSUD DR Moewardi Surakarta. Skripsi. Surakarta: Fakultas Kedokteran Universitas Sebelas Maret; 2008.

[16]Fauzi, A. Gambaran harapan penderita tuberkulosis paru terhadap pengawas minum obat di daerah pedesaan Kabupaten Sleman, Yogyakarta 2008. Skripsi [Internet]. 2008 [Diakses pada tanggal 13 Januari 2017]. Tersedia di: https://skripsistikes.wordpress.com/2009/05/ 03/ikpiii6/.

[17]Widjanarko, B., Prabamurti, PN., dan Widyaningsih, N. Analisis faktor-faktor yang mempengaruhi praktik pengawas menelan obat (PMO) dalam pengawasan penderita tuberkulosis paru di Kota Semarang. Jurnal Promosi Kesehatan Indonesia. 2006: 1(1): 15-24.

[18]Saftarina, F., Islamy, N., dan Mutiara CR. Hubungan pendidikan dan pengetahuan pengawas minum obat (PMO) terhadap keteraturan minum obat anti tuberkulosis (OAT) pada penderita tuberkulosis paru di Kabupaten Tulang Bawang Barat. Prosiding Seminar Nasional Sains MIPA dan Aplikasi. Juni 2012: 3(3):349-354. 
Pratama, et al., Hubungan Antara Tingkat Pengetahuan Pasien dan Pengawas Menelan Obat (PMO)....

[19]Siswanto, PI., Yanwirasti, dan Elly, U. Hubungan Pengetahuan dan Dukungan Keluarga dengan Kepatuhan Minum Obat Anti Tuberkulosis di Puskesmas Andalas Kota Padang. Jurnal Kesehatan Andalas. 2015: 4(3): 724-728.

[20]Devaus, DA. Survey in Social Research, $5^{\text {th }}$ Edition. New South Wales: Allen and Unwin; 2002.

[21]Pasek, M. S. \& I. M. Satyawan. Hubungan persepsi dan tingkat pengetahuan penderita
TB dengan kepatuhan pengobatan di Kecamatan Buleleng. Jurnal Pendidikan Indonesia. 2013: 2(1): 150

[22]Mukhsin. Faktor-faktor yang mempengaruhi keteraturan minum obat pada penderita TBC paru yang mengalami konversi di Kota Jambi. Tesis. Yogyakarta: Pasca Sarjana UGM; 2011. 